\title{
Seismic Hazard Analysis of Maumere, Flores: a Review of the Earthquake Sources
}

\author{
Lina Handayani ${ }^{1}$ \\ \{lina.handayani@gmail.com ${ }^{1}$ \} \\ Research Center for Geotechnology, Indonesian Institute of Sciences \\ Kampus LIPI, Jl. Sangkuriang Bandung 40135 ${ }^{1}$
}

\begin{abstract}
Maumere at the north coast of Flores Island has experienced not only large earthquakes but also tsunamis. The earthquake sources in this area include thrust faults (north of the island, Timor Trough, and Sawu Basin), strike-slip fault at the west of the island, and Australian Plate subduction-related movements. In this paper, we reviewed all tectonic aspects and studies on a previous large earthquake. A thorough study of all possible sources and probability seismic hazard analysis indicated that events caused by the Flores back arc thrust has the highest possible effect to the ground attenuation in Maumere.
\end{abstract}

Keywords: seismic hazard, Maumere, Flores, Flores back arc thrust.

\section{Introduction}

Earthquakes events have continually occurred around the island of Flores. One of the largest earthquakes in this area occurred on December 12,1992, with a magnitude of 7.8. The main shocks, aftershocks and the ensuing tsunami hit the northern coast. Maumere as one of the largest town suffered a big loss and destruction. Such loss can be minimized by a better understanding of the earthquakes that may affect an area. It is more imminent now when Maumere is developing with increasing population and infrastructures. The knowledge then should be followed by public education, emergency preparedness, and construction of earthquake-resistant infrastructures. The earthquake catalog was recorded 4 large events with a magnitude of more than 7 that had affected Maumere. Three of them occurred in the Flores Sea, in the year of 1996, 1992, and 2015. The other one, the 2004 event, had the epicenter in the Timor Sea. A devastating event in 1992 also caused a tsunami that destroyed most of the northern coast, including Maumere.

Maumere is a town in the north of Flores Island, which is in an active zone of earthquakes. Tectonic setting around Flores Island can be seen on Figure 1. Historical epicenters are distributed on all sides of the island. Therefore, the significance of earthquake sources studies is very applicable. In this paper, the earthquake's epicenters are classified into their tectonic sources, and the probability of peak ground acceleration for each zone is calculated. 


\section{Tectonic and geology setting}

Flores Island is located in the middle of tectonically active area, which is defined by several plate/micro-plates boundaries. The area is the east end of Indo-Australian plate subduction toward Eurasia, which elongated from north of Sumatra and Java. It is also the western boundary of a collision of continental Australian Plate toward the Banda plate [1],[2],[3]. This transition zone is also characterized by more complicated crust structures in the area that shown in Figure 1.

At the north coast of Flores Island, the Flores back thrust is elongated along the island and connected to the Wetar Thrust at the east. Flores's back-arc thrust was considered to develop due to the contraction between the Banda backarc and the Australian continent [4],[5]. It might explain the other thrust boundaries, which also present at the south of Flores, as well. On the other hand, the thrust at the south of Sumba is accountable to the uplift of the island. Savu Island is bounded by thrusts at north and south, which might initiate the rose of the island. Ely [6] suggested that the subducted of the Scott Plateau, between oceanic and Australian continental plate, had resulted in a stress that caused the uplift of the arc where Savu and Roti islands emerged.

In the west of Timor, the Semau Fault is a left-lateral strike-slip fault, which is also the boundary between the Sumba and Timor blocks according to a GPS study [7]. Savu Basin, between Flores and Timor islands, was part of Sunda-Banda forearc, with the former trench should be at its south but buried beneath recent Australian plate [4].

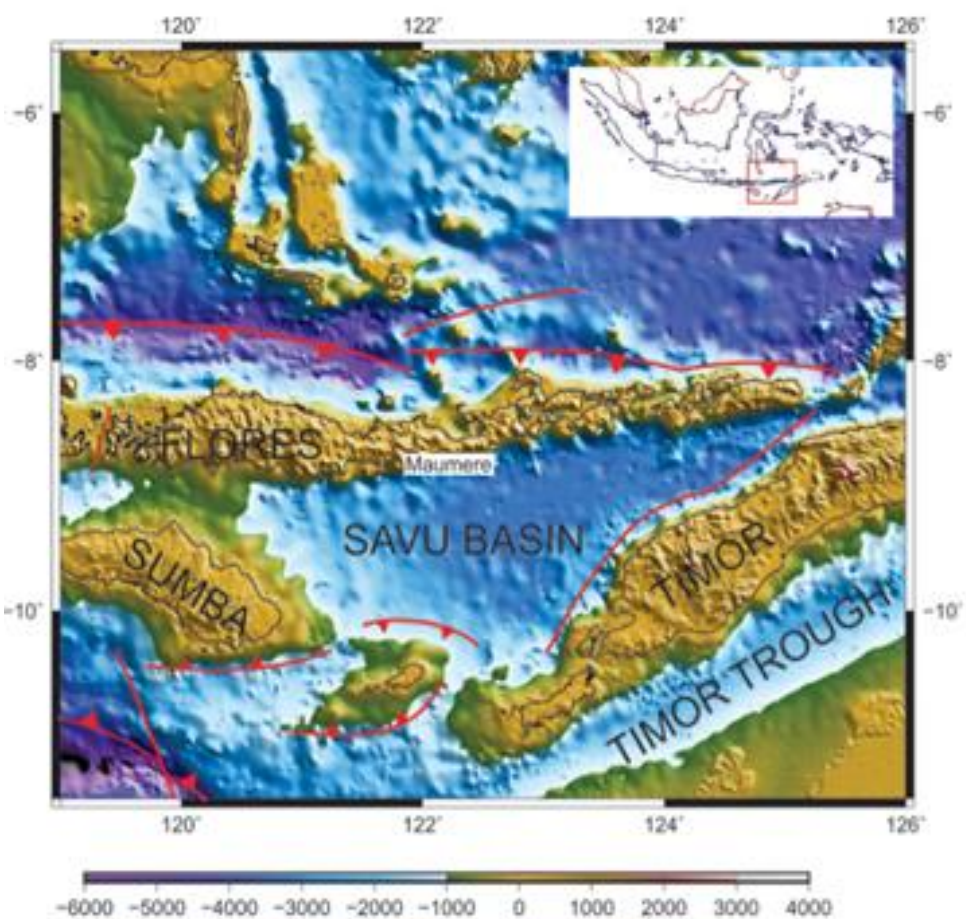


Fig. 1. Tectonic setting around Flores Island (based on McCaffrey 1991, Harris 2011).

\section{Data and methods}

Earthquakes data are from IRIS (Incorporated Research Institute for Seismology) catalog that covered all data from the earliest record ( 1970) to July 2019. The depth distribution of epicenters explains the related tectonic activity of the area. The seismicity map in Figure $\mathbf{2}$ has depth classified into three groups: shallow for events with the depth less than $70 \mathrm{~km}$, intermediate for events more than $70 \mathrm{~km}$ but less than $300 \mathrm{~km}$, and deep for events more than $300 \mathrm{~km}$.

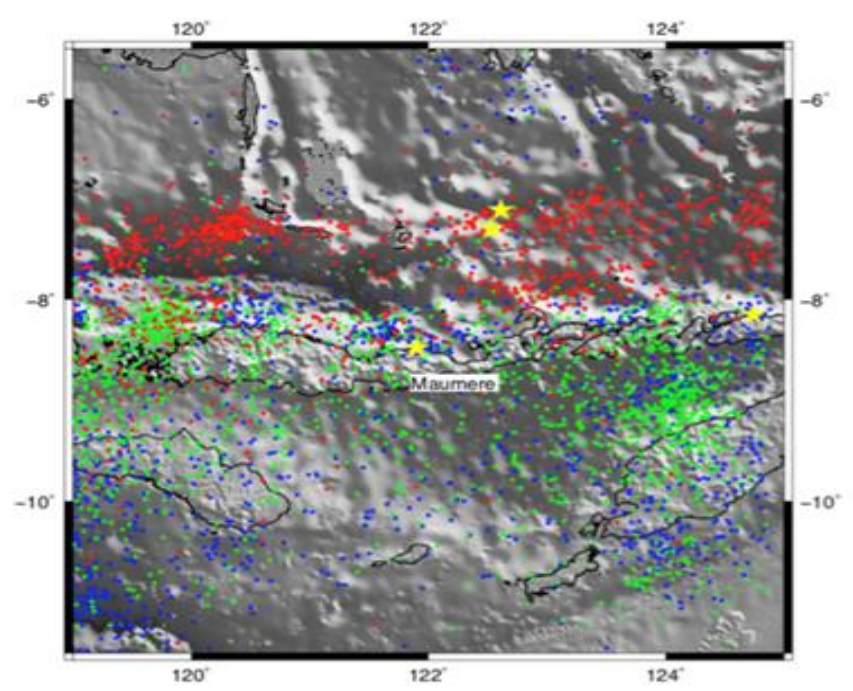

Fig. 2. Epicenter distribution (1970 - 2019) (source: IRIS). Yellow star for $M>7$, green circle for $M$ between 5 and 7 , blue circles for $\mathrm{M}<5$.

The probability of seismic hazard analysis was applied to define the zone where the epicenter has the highest possible consequence to Maumere. The peak ground attenuation (PGA) was calculated from each zone. Then, the seismic hazard probability was also analyzed for each. Attenuation equations were generated for different types of sources and geological conditions [8]. For subduction-related sources, Boore 1997's equation is one from several tha has generally applied [8],[9]. Boore equation provided several constants for every type of source. Equation (1) is the attenuation equation for strike-slip segments.

$$
\log Y=0.313+0.527(M \quad 6) \quad 0.778 \log r \quad 0.371 \log \frac{V S}{1396}
$$

Different constants are applied for other segments, as in equation (2).

$$
\log Y=0.242+0.527(M \quad 6) \quad 0.778 \log r \quad 0.371 \log \frac{V S}{1396}
$$


where:

$r=\sqrt{d^{2}+5.57}, d$ is the distance to the epicenter, $M$ is magnitude, $V_{s}$ is $\mathrm{S}$ seismic velocity at the depth of $30 \mathrm{~m}$, and $Y$ is the horizontal ground movement in $g$. Attenuation value or PGA is in $\mathrm{g}\left(1 \mathrm{~g}=9.81 \mathrm{~m} / \mathrm{s}^{2}\right.$ or $\left.1 \mathrm{~g}=981 \mathrm{Gal}\right)$.

The geological map from the Geological Survey of Indonesia has divided the Flores Island into 2 parts, west (Ruteng) and east (Ende). Maumere is located within the Ende region, in the area of volcanic rock (lava, pumice breccia, tuff) of Quarter - Tersier (Qtv) [10]. To calculate the peak ground acceleration, I used Vs $360 \mathrm{~km} / \mathrm{s}$ for the Quarter volcanic rock [11], [12].

\section{Result and discussion}

\subsection{Seismicity Analysis}

The movements or types of events are better explained by a focal mechanism map can be seen on Figure 3. The deep events at the Flores Sea are dominated by normal faults. And all shallow events at the north coast of Flores Island are thrust in nature. Thrust faults are also found in the south of Sumba, south of Timor, and in the east of Savu Basin. But normal movements also appear sporadically at Savu Basin, mostly at the west part. Some strike-slip movements appear at the strait between Sumbawa and Flores Island. Normal faults are also responsible for earthquakes with epicenters near the trench south of Sumba.

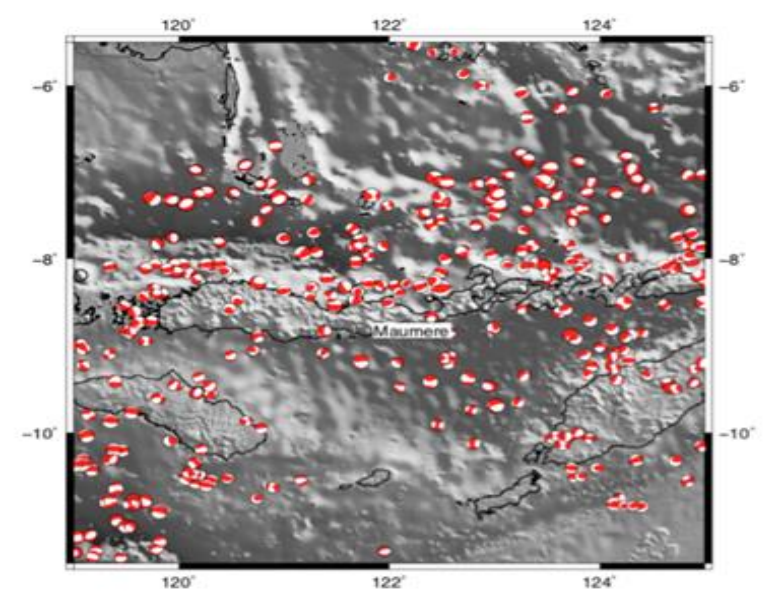

Fig. 3. Focal Mechanism (source: CMT Harvard).

The shallow events (blue) are distributed almost in all areas unevenly. The largest clusters are at the coastline of the north of Flores Island, at the sea south of Sumba, Savu Basin, and south of Timor. Intermediate events mostly distributed Strait at the west of Flores Island and at the east of Savu Basin. The deep events mostly distributed at the Flores Sea.

A thorough study of the seismicity in this area has been written by Ely and Sandiford [6]. They classified the area into 4 zones of shallow to intermediate earthquakes. Added with the deep earthquakes, then the earthquake sources in this area are classified into 5 zones. First is the Flores back arc thrust zone at the north of the island, with shallow to intermediate thrust 
earthquakes. Second is the shallow and intermediate thrusts zone in Timor Through. The third zone is the intermediate depth thrusts in the middle of Savu Basin and normal in the east. The fourth zone is in between Sumbawa and Flores Islands, where active events are mostly strikeslip with intermediate depth. Fifth is the subduction earthquakes zone, which consists of the deep normal movement at the northern Flores Sea, and the shallow normal earthquakes at the south of Sumba.

A study and modeling of Flores earthquake on December 12, 1992, indicated that the movement was a shallow dipping thrust, with depth $9 \mathrm{~km} \mathrm{[13].} \mathrm{The} \mathrm{source} \mathrm{was} \mathrm{very} \mathrm{shallow}$ and contributed to a very large tsunami. Further seismic study using source inversion indicated the ENE inclination of the rupture, instead of EW as the trend of the back-arc thrust [14]. In Wetar and Timor area, intermediate events varied not only in the magnitude but also in the character, some normal, some thrusts and a few strike slips. It might reflect the complexity of the deformation occurred in this particular area [15].

\subsection{PGA Analysis}

Flores Thrust Zone at the north of the island is the closest possible earthquake source with shallow events. There are only three (3) recorded events for large earthquakes $(M>7)$ : 1992, 2004 and 2012. For probability calculation, we combined all events with $M>6$. Table 1 presents the PGA calculation for each type of source with several possible magnitudes. The highest PGA due to the Flores Thrust is $0.122 \mathrm{~g}$. Fault movement at the south of Timor Island caused shallow events with low magnitude $(\mathrm{M}<5.5)$. But the distance is too far from the town. So the highest PGA due to the Timor Trough activity is $0.01 \mathrm{~g}$. Savu basin has more complex characteristics. Two tectonic activities in Sawu: thrust with deep earthquake $(>100 \mathrm{~km})$ and strike-slip fault with shallow earthquake.

The highest PGA due to the epicenter in Sawu Basin is $0.03 \mathrm{~g}$. But for all events in this basin (M 5.5) only has PGA value as 0.013. Events occurred in the strait between Sumbawa Island and Flores Island mostly strike-slip, has Magnitude less than 6, and mostly deep sources (> $100 \mathrm{~km}$ ). The highest PGA estimation for the event with a magnitude of 6 from this source is $0.01 \mathrm{~g}$. The study area is affected by the activity of subduction. There are several types of sources: deep, intermediate and shallow epicenters. Two large events in the Flores Sea with magnitude more than 7 had a depth of more than $500 \mathrm{~km}$ (occurred in 1996 and 2015). For this source, the highest PGA estimation is $0.03 \mathrm{~g}$.

\section{Conclusion}

The location of Maumere, Flores, is within the close distance of several possible sources of earthquakes. The closest and the deadliest is the Flores back arc thrust. The highest PGA estimated for Maumere is $0.122 \mathrm{~g}$, which is the PGA for earthquake with the source in Flores back arc thrust. Other sources caused relatively smaller PGA-s due to the distance and the magnitude of the event. However, the frequency of events is very high. Therefore, mitigation and education of the possible earthquake and tsunami hazard should be given constantly.

Table 1. Probability of PGA for each type of event.

\begin{tabular}{ccc}
\hline Epicenter Zone & M & PGA (g) \\
\hline
\end{tabular}




\begin{tabular}{lcc}
\hline \multicolumn{1}{c}{ Epicenter Zone } & M & PGA (g) \\
\hline Flores Thrust & 5 & 0.030 \\
& 6 & 0.050 \\
& 7 & 0.122 \\
Deep subduction (North Flores Sea) & 5 & \\
& 6 & 0.011 \\
Shallow subduction (South of Sumba) & 5 & 0.019 \\
& 6 & \\
Timor Trough & & 0.006 \\
& & 0.010 \\
Savu Trough/Basin & 5 & \\
& 5.5 & 0.007 \\
& & 0.010 \\
& & \\
Sumbawa Strait & 5 & 0.010 \\
& 5.5 & 0.013 \\
& 6 & 0.017 \\
& 7 & 0.030 \\
& & \\
& 5.5 & 0.006 \\
& 6 & 0.008 \\
& 5 & 0.010 \\
\hline
\end{tabular}

\section{References}

[1] Audley-Charles, M. G.: Ocean trench blocked and obliterated by Banda forearc collision with Australian proximal continental slope. Tectonophysics, vol. 389, pp. 65-79 (2004)

[2] Harris, R.: The Nature of the Banda Arc-Continent Collision. In Arc-Continent Collision, D. Brown and P. D. Ryan, Eds. Springer Berlin Heidelberg, pp. 163-211 (2011)

[3] McCaffrey, R. and Abers, G. A.: Orogeny in arc-continent collision : The Banda arc and western New Guinea. Geology, vol. 19, pp. 563-566 (1991)

[4] Rigg J. W. D. and Hall, R.: Neogene development of the Savu Forearc Basin, Indonesia. Mar. Pet. Geol., vol. 32, no. 1, pp. 76-94 (2012)

[5] Koulali, A., Mcclusky, S., Susilo, S., Leonard, Y., Cummins, P., Tregoning, P., Meilano, I., Efendi, J., and Wijanarto, A. B. The kinematics of crustal deformation in Java from GPS observations: Implications for fault slip partitioning. Earth Planet. Sci. Lett., vol. 458, pp. 69-79 (2017)

[6] Ely K. S., and Sandiford, M.: Seismic response to slab rupture and variation in lithospheric structure beneath the Savu Sea, Indonesia. Tectonophysics, vol. 483, pp. 112-124 (2010)

[7] Koulali, A., Susilo, S., Mcclusky, S., Meilano, I., Cummins, P., Tregoning, P., Lister, G., Efendi, J., and Syafi, M. A..: Crustal strain partitioning and the associated earthquake hazard in the eastern Sunda-Banda Arc. Geophys. Res. Lett., vol. 43, pp. 1943-1949 (2016)

[8] Douglas, J.: A comprehensive worldwide summary of strong motion attenuation relationships for peak ground acceleration and spectral ordinates (1969 to 2000). Imperial College, UK, (2001)

[9] Baker, J. W.: Introduction to Probabilistic Seismic Hazard Analysis. White Paper Version 2.1 (2015) [10] Suwarna, N., Santosa, S., and Koesumadinata, S.: Geological map of the Ende quadrangle, East Nusa Tenggara. Geological Research and Development Center (1989)s 
[11] Wills, C. J., Petersen, M., Bryant, W. A., Reichle, M., Saucedo, G. J., Tan, S., Taylor, G., and Treiman, J.: A Site-Conditions Map for California Based on Geology and Shear-Wave Velocity. Bull. Seismol. Soc. Am., vol. 90, no. 6B, pp. 187-208 (2000)

[12] Petersen, M. D., Dewey, J., Hartzell, S., Mueller, C., Harmsen, S., Frankel, A., and Rukstales, K.: Probabilistic seismic hazard analysis for Sumatra, Indonesia and across the Southern Malaysian Peninsula. Tectonophysics, vol. 390, no. 1-4, pp. 141-158 (2004)

[13] Hidayat, D., Barker, J. S., and Satake, K.: Modeling the Seismic Source and Tsunami Generation of the December 12, 1992, Flores Island, Indonesia, Earthquake. Pure Appl. Geophys., vol. 144, no. 3/4, pp. 537-554 (1995)

[14] Pranantyo I. R., and Cummins, P. R.: Multi-Data-Type Source Estimation for the 1992 Flores Earthquake and Tsunami. Pure Appl. Geophys., vol. 176, pp. 2969-2983 (2019)

[15] Sandiford, M.: Seismic moment release during slab rupture beneath the Banda Sea. Geophys. J. Int., vol. 174, pp. 659-671 (2008) 